\title{
NOTES
}

\section{DEFINITION OF THE MARKET IN TYING ARRANGEMENTS: ANOTHER ASPECT OF TIMES-PICAYUNE*}

IN a tying arrangement, a seller or buyer conditions his dealing with others in a market which he controls upon their dealing with him in a market where he must compete. ${ }^{1}$ Such use of monopoly power in one market to secure an advantage over competitors in another often runs afoul of the antitrust laws.? A seller who uses tying arrangements to "lease or make a sale [of] commodities" may violate Section 3 of the Clayton Act. ${ }^{3}$ But buyers' practices

*Times-Picayune Publishing Co. v. United States, 345 U.S. 594 (1953).

1. Tying arrangements have been the subject of frequent definition. An excellent example appears in Lockhart and Sacks' definitive article on exclusive arrangements: "The distinctive feature of a tying arrangement is that a supplier furnishes a controlled product, over which it usually has some degree of market control, on condition that the user or dealer also purchase a tied product that would otherwise be available from the supplier's competitors." Lockhart \& Sacks, The Relecance of Economic Factors in $D_{C}$ termining Whether Exclusize Arrangements Fiolate Setion 3 of the Clayfon Acl, 65 HaRv. L. REv. 913, 942 (1952). For a similar definition see Times-Picayune Publishing Co. v. United States, 345 U.S. 594, 614 (1953). One feature of these definitions is their limitation to tying practices of sellers or lessors who overtly refuse to deal solely in the "tying product." Recent extension of the tying arrangement dactrine to cover subtler methods of coercion, and also buyers' as well as sellers' practices, necessitates more comprehensive definition. See note 44 infra. In United States $v$. Griffilh, where coercion was inferred from buyers' simultaneous negotiations for exclusive rights in competitive and non-competitive markets, and where two "products" were not actually "ticd," the Court isolated the essential offensiveness of tying arrangements: "The consequence of such a use of monopoly power is that films are licensed on a non-competitive basis in what otherwise would be competitive situations." United States v. Grifith, 334 U.S. 100, 108 (1948).

On tying arrangements generally see Kahn, $A$ Lcgal and Economic Approisol of the "New" Sherman and Clayton Acts, 63 Y ALE L.J. 293, $322-7$ (1954); Lodthart \& Sacls," supra at $942-54$.

2. International Salt Co. v. United States, 332 U.S. 392 (1947) (leases of patented salt dispensing machines conditioned on lessee's purchase of lessor's salt held to violate $\$ 1$ of Sherman Act, and $\$ 3$ of Clayton Act) ; International Business Machines Corg. v. United States, 298 U.S. 131 (1936) (tying of tabulating cards to computing machines violates §3); Automatic Canteen Co. of America v. FTC, 194 F.2d 433 (7th Cir. 1952) (tying leases of vending machines to sales of candy violates \$3). But ef. Picl: Mffg. Co. v. General Motors Corp., 299 U.S. 3 (1936) (no $\$ 3$ illegality where sales of replacement parts tied to sales of automobiles, because of reasonable relationship to preservation of manufacturer's good will) ; FTC v. Sinclair Refining Co., 261 U.S. 463 (1923) (tying of gasoline sales to leases of pumps approved for same reason).

3. Section 3 forbids "any person ... to lease or malse a sale or contract for sale . . . on the condition, agreement, or understanding that the lessee or purchaser thereof shall not use or deal in the goods... or other commodities of a competitor or competitors of 
are not covered. And Section 3 is limited to leases and sales of tangible commodities. Thus, tying sales of hazard insurance to mortgage loans does not violate the Clayton Act, because a loan is not a lease or sale, and money is not a commodity. ${ }^{4}$ However, no such limitations are found in the Sherman Act. ${ }^{5}$ General Motors' policy of refusing to sell automobiles unless purchasers used GM financing unreasonably restrained trade under Section $10^{\circ}$ And motion picture exhibitors who used buying power in one-theatre towns to negotiate for films in competitive towns also violated the Act. ${ }^{7}$

In the Times-Picayune case, ${ }^{8}$ where the Government attacked forced combination sales of newspaper advertising ${ }^{0}$ under the Sherman Act, ${ }^{10}$ the

the lessor or seller ... .where the effect ... may be to substantially lessen competition or tend to create a monopoly in any line of commerce." 38 STAт. 731 (1914), 15 U.S.C. $\$ 14$ (1946).

The condition not to deal in the goods of another can be inferred from the practical effects of a tying arrangement. See cases cited in Times-Picayune Publishing Co. v. United States, 345 U.S. 594, 607 n.23 (1953).

4. United States v. Investors Diversified Services, Inc., 102 F. Supp. 645 (D. Minn. 1951) ; cf. Fleetway, Inc. v. Public Service Interstate Trans. Co., 72 F.2d 761. (3d Cir. 1934) (provisions of $\$ 2$ of Clayton Act held inapplicable to bus fares for same renson).

5. 26 STAT. 209 (1890), 15 U.S.C. $\$ \$ 1,2$ (1946). Tying arrangements may be attacked as unreasonable restraints of trade under $\$ 1$, International Salt Co. v. United States, 332 U.S. 392 (1947); United States v. Griffith, 334 U.S. 100 (1948), or under the $\$ 2$ pro* hibition against monopolizing. United States v. Griffith, supra.

6. United States v. General Motors Corp., 121 F.2d 376 (7th Cir. 1941). Sce also United States v. National City Lines, Inc., 186 F.2d 562 (7th Cir.), cert. denicd, 341 U.S. 916 (1951) (tie-in of exclusive supply contracts to loans held illegal under $\$ 2$ ).

7. United States v. Griffith, 334 U.S. 100 (1948).

8. Times-Picayune Publishing Co. v. United States, 345 U.S. 594 (1953). For fuller statement of the facts, see Kahn, A Legal and Economic Appraisal of the "New" Sherman and Clayton Acts, 63 Yale L.J. 293, $324-7$ (1954). See also, Notes, 53 CoL. L. Rev. 1011 (1953) ; 102 U. of Pa. L. Rev. 125 (1953). And see The Supreme Court, 1952 Tcm, 67 HaRv. L. Rev. 91, 128 (1953).

9. Also known as "unit selling" plans, forced combination sales of advertising space are widespread in the newspaper industry; the outcome of the Times-Picaynme case was a matter of concern to about 180 publishers who tied advertising sales in their morningafternoon combinations. Times-Picayune Publishing Co. v. United States, 345 U.S. 594, 604 (1953). See Comment, Local Monopoly in the Daily Nezespaper Indistry, 61 YaLE L.J. 948,989 (1952).

10. The Government made no attempt to attack the Publishing Company's unit plan under the Clayton Act, referring, on oral argument, to an informal opinion of the Federal Trade Commission that advertising was not a "commodity" within the meaning of $\$ 2(a)$ of the Robinson-Patman Act, 49 STar. 1526 (1936), 15 U.S.C. $\$ 13$ (a) (1946); 81 ConG. REC. 2336-7 (1937) ; Times-Picayune Publishing Co. v. United States, supra note 9, at 60910 n.27. See text at notes 3, 4 supra. Although the Supreme Court declined to comment on this issue, footnote 27 refers to the Commission's opinion as an "early" one, and the matter appears still open to adjudication. Ibid. For suggestion that the Court was "invit[ing] an attack upon unit advertising space arrangements based upon $\$ 3$," see Mattson, Condition that the Lessee or Purchaser Shall Not Deal in the Goods of a Competitor in American Bar Association Section of Antitrust law 97, 101. (1953). 
Supreme Court for the first time established per se criteria ${ }^{11}$ to test the Section 1 legality of tie-in sales. The Court held that such arrangements are illegal per se only when a "seller ${ }^{12}$ enjoys a monopolistic position in the market for the "tying' product" and when "a substantial volume of commerce in the 'tied' product is restrained." 13 Since most tying arrangements will affect a "substantial volume of commerce,"14 proof of defendant's market

11. The Tines-Picayune statement of criteria for per se illegality under $\$ 1$ of Sherman was the first comprehensive pronouncement in this area. Only a fev prior Supreme Court decisions had invalidated tying arrangements under the Sherman Act. Intcriotional Salt, which held that arrangements tying purchases of salt to leases of machines were illegal per se under $\S 1$, as well as $\S 3$ of Clayton, left doubt whether the same result would obtain where the tying product was not patented and $\S 3$ was not involved. International Salt Co. v. United States, 332 U.S. 392 (1947). But see Note, $4 S$ CoL L. Rev. 733, 740 (194S). Cf. United States v. Paramount Pictures, Inc., 334 U.S. 131, 156-9 (1948), invalidating "blocl:booking," or forced package sales of two or more copyrighted motion pictures. And insofar as Griffith concerned $\$ 1$, it did not treat per se violation. United States v. Griffith, 334 U.S. 100 (1948). See notes 5 supra and 16 infra. See also Schine Chain Theatres, Inc v. United States, 334 U.S. 110 (1948), the companion case to Griffith.

12. While the Court refers to "sellers" throughout the opinion, the Sherman Act criteria set out, as well as the Court's subsequent discussion of market definition, see page 395 infra, would appear equally applicable to buyers, particularly in the light of United States v. Griffith, 334 U.S. 100 (1948), stspra note 1.

13. Times-Picayune Publishing Co. v. United States, 345 U.S. 594, 609-10 (1953).

Dicta also substantiated prior indications that as long as a quantitatively substantial volume of commerce in the tied market was affected, any tying arrangements falling within $\$ 3$ language would be invalid under the Clayton Act. Id. at 608-09. See note 3 sissra and accompanying text. In International Salt, which first enunciated the "quantitative effect" test, the fact that the tying product was patented left open the possibility that stricter proof would be required where no patent was involved. See also Oxford Varnish Corp. v. Ault \& Wiborg Corp., 83 F.2d 764, 766 (6th Cir. 1936) (arrangement tying purchases of paint and varnish to lease of patented graining plates violated $\$ 3$ of Clayton where lessor's proportionate share of national paint and varnish production was approximately one and one-half percent). And for further discussion of this test, see Note, $48 \mathrm{CoL}$ L. REv. 733, 740-1 (1948). But dicta in Standard Oil Co. v. United States, 337 U.S. 293 (1949), which involved not tying arrangements but agreements to purchase all the customers' requirements from defendant, indicated that quantitative effect alone would be sufficient to invalidate a tying arrangement under the Clayton Act. Id. at 307-05. The Times-Picoyure opinion, in comparing criteria for illegality under Clayton and Sherman, supports this view, stating that either proof of monopoly position in the tying market or proof that a substantial amount of commerce in the tied product was affected, would be sufficient for illegality under $\$ 3$. Times-Picayune Publishing Co. v. United States, supra at 608-09.

But for a view questioning the Court's intention to malse this a de minimis requirement, see The Suprene Court, 1952 Terrm, 67 Harv. L. Rev. 91, 130 (1953).

14. The Court in Times-Picayme did not decide whether the "substantial volume of commerce" necessary to condemn tying arrangements under $\$ 1$ is the same as that suffcient under $\$ 3$ of the Clayton Act. Times-Picayune Publishing Co. v. United States, 345 U.S. 594, $610 \mathrm{n} .28$ (1953). However, in International Salt, the Court employed a quantitative measure of the volume of commerce affected for purposes of both the Clayton and Sherman Acts. International Salt Co. v. United States, 332 U.S. 392, 395-6 (1947). And the Court made short work of the requirement, basing its decision that "the volume of business 
position will be decisive in establishing per se illegality, except where a patented or copyrighted tying product provides prima facie evidence of market control. $^{15}$ And evidence of an important market position short of monopoly is also relevant in determining whether use of such arrangements, though not illegal per se, unreasonably restrains trade or constitutes monopolization. ${ }^{10}$

affected by [defendant's] contracts cannot be said to be insignificant or instbstantial . .." solely upon evidence that the Company's sales of salt affected by the arrangement amounted to $\$ 500,000$ in 1944. Id. at 396 . See also Oxford Varnish Corp. v. Ault \& Wiborg Corp., supra note 13. A recent discussion suggests that the severity of the "substantial effect" rcquirement might, in $\S 1$ cases, be made to depend upon the extent of market dominance in the tying product. The Supreme Court, 1952 Term, 67 HARv. L. REv. 91, 130 (1953).

15. See Standard Oil Co. v. United States, 337 U.S. 293, 307 (1949) : "A patent, . . although in fact there may be many competing substitutes for the patented article, is at least prima facie evidence of [market] control." See also Transparent-Wrap Machine Corp. v. Stokes \& Smith Co., 329 U.S. 637, 640 (1947). Even prior to the Clayton Act, courts had forbidden enlargement of the scope of the patent monopoly by tying arrangements. See, e.g., Motion Picture Patents Co. v. Universal Film Mfg. Co., 243 U.S. 502 (1917) (sales of patented film projectors making right to use machines contingent upon use solely to show films leased by seller held illegal).

For discussion of the doctrine that patentees must be held to higher standard under the antitrust statutes than owners of other kinds of property, see Note, 57 YALE L.J. 1298 (1948).

16. See note 5 silpra. In the GMAC case, where the unreasonableness but not per se illegality of the tying arrangement was at issue, the Court referred to dicta in Apex Hosiery Co. v. Leader, 310 U.S. 469 (1940), to the effect that market control is an essential element of all $\$ 1$ violations. United States v. General Motors Corp., 121 F.2d 376, 403 (7th Cir. 1941). A degree of market control equivalent to that necessary for per se illegality would not be necessary to establish the unreasonableness of the tying arrangement under $\$ 1$. However, the strict criteria for proof of per se violation are intended to eliminate the need for considering other variables among which market position is only one relevant to a "rule of reason" analysis. Thus in Times-Picayune, the Court said: "[O]ur inquiry to determine reasonableness under $\S 1$ must focus on the percentage of business controlled, the strength of the remaining competition and whether the action springs from business requirements or purpose to monopolize." 'Times-Picayune Publishing Co. v. United States, 345 U.S. 594, 615 (1953). See also United States v. Columbia Steel Co., 334 U.S. 495, 522 (1948). And see pages $396-7$ infra.

Practices not illegal in themselves may, when engaged in by a monopolist, be the basis for an inference of general intent to monopolize. Thus legal monopoly of the type conferred by ownership of the sole theatre in a town, or by patent or copyright, will facilitate proof of a $\$ 2$ violation where, as in Griffith, the legal monopoly is used in a tying arrangement. See United States v. Griffith, 334 U.S. 100, 105-107 (1948); United States v. Aluminum Co. of America, 148 F.2d 416, 431-2 (2d Cir. 1945). And see Rostow, Monopoly Under thi Sherman Act: Power or Purpose?, 43 ILL. L. Rev. 745 (1949). In view of these severe con* sequences of being termed a "monopolist" under $\$ 2$, it would appear probable that the requirement of "monopolistic position" necessary to invalidate a tying arrangement under $\S 1$ is less stringent than that of $\S 2$. The alternative use of "market dominance" for "monopolistic position" lends support to this idea. See Times-Picayune Publishing Co. v. United States, 345 U.S. 594, 613, 614 (1953). And see United States v. American Can Co., 87 F. Supp. 18 (N.D. Cal. 1949) (defendant controlled 54\% of tying product-held illegal). Sec also Kahn, A Legal and Economic Appraisal of the "New" Sherman and Claytan Acts, 63 YALE L.J. 293, 322-4 (1954). But in Times-Picayine, 40\% of the relevant market was held insufficient for "market dominance." See text at note $30 \mathrm{infra.}$ 
In Times-Picayune, the Court's definition of the relevant market defeated allegations that the sole morning newspaper in New Orleans enjoyed a monopolistic or dominant position. The defendant Publishing Company had tied sales of national and classified advertising in that paper ${ }^{17}$-the largest in the city ${ }^{18}$ - to sales in one of two competing afternoon newspapers. Rejecting both the Government's claim that the morning newspaper occupied a distinct market, ${ }^{19}$ and defendant's contention that other advertising media, because they competed with newspapers, should be included in their market, ${ }^{20}$ the Court found that the only relevant market ${ }^{21}$ was one which included all three newspapers. ${ }^{22}$ Using this definition of the market, a $5-4$ majority ${ }^{23}$ held

17. The tied newspapers were the morning Times-Picayune and the evening States. The independently owned evening Item was the only other daily in New Orleans.

18. The Times-Picayune far surpassed the States and the Item in both circulation and linage. Thus, 1950 data showed a daily average circulation of 188,402 for the TimesPicayune, 114,660 for the Item, and 105,235 for the States. Times-Picayune Publishing Co. v. United States, 345 U.S. 594, 599 (1953). And "[d]uring the four years preceding the introduction of the unit rate the Times-Picayune carried in excess of $50 \%$ more general display advertising than the States or the Item." United States v. Times-Picayune Publishing Co., 105 F. Supp. 670, 676 (E.D. La. 1952).

The Supreme Court measured the Times-Ficayune's share of the marliet solely in terms of linage, on the theory that circulation figures were a measure only of its success in selling to its readers. 345 U.S. 594, 610, 612 (1953). But since the Court defined circulation as the product sold to advertisers, taking linage figures alone appears inconsistent with the usual practice of measuring market share in terms of the percentage of units of product sold. See, e.g., Judge Hand's computation of Alcoa's share of the marlet in United States v. Aluminum Co. of America, 148 F.2d 416, 423 (2d Cir. 1945). And since, in addition to nurmal price differences, linage rates vary sharply in proportion to the size of a newspager's circulation, neither treatment would appear entirely indicative. Thus in actual practice, price of advertising space is quoted in "line" and "milline" rates, the latter amalgamating linage rate with circulation. Comment, Local Monopoly in the Doily Newspaper Industry, 61 YALE L.J. 948, 977 (1952).

19. Brief for Appellant, United States of America, pp. 28-9, Times-Picayune Publishing Co. v. United States, 345 U.S. 594 (1953).

20. Brief for Appellant, Times-Picayune Publishing Co., p. 79, Times-Picayune Publishing Co. v. United States, 345 U.S. 594 (1953). For a more detailed statement of this contention see Brief on Behalf of 98 Newspaper Publishers as Amici Curiac, pp. 16-24, Times-Picayune Publishing Co. v. United States, supro.

21. As the Court suggests, market position usually is measured by first defining a single relevant market and then estimating the defendant's share. Times-Picayune Publishing Co., 345 U.S. 594, 611 (1953), citing with approval, United States v. Culumbia Steel Co., 334 U.S. 495, 524 (1948). And see United States v. Aluminum Co. of Ameriea, 148 F.2d $416, \$ 24$ (2d. Cir. 1945). But an alternative approach talien in some cases is to look at the defendant's percentage share in each of a number of possible relevant markets. See, c.g., American Tobacco Co. v. United States, 328 U.S. 781, 794-800 (1946); Lnited States v. American Can Co., 87 F. Supp. 1S, 21-2 (N.D. Cal. 1949). In cases where defendant is charged with completed monopoly of a particular line of commerce or illegal use of leverage in one market to gain an advantage in another, it may be essential to single cut one relevant market. But see pages 397-\$ infra.

22. Times-Picayune Publishing Co. v. United States, 345 U.S. 594, 613, 614 (1953).

23. Id. at 594. Mr. Justice Clark delivered the opinion of the Court. Mir. Justice Burton dissented, joined by Justices Black, Douglas, and Minton. Id. at 628. 
that the Publishing Company's advertising contracts were not illegal per se.24 The morning newspaper, or "tying product," having only 40 percent of a market shared with two other newspapers, lacked a dominant position.20 Second, by finding that the relevant market included all three newspapers, the Court precluded a determination that defendant had tied sales in competitive and non-competitive markets. ${ }^{26}$ Finally, viewing the forced combination sales not as tying arrangements, but under the Sherman Act's general prohibitions, the Court found neither unreasonable restraint of tracle nor attempt to monopolize. ${ }^{27}$

To reach its definition of the market, the Court reasoned that all three newspapers sold indistinguishable units of the same product, which it defined as New Orleans newspaper advertising readership. ${ }^{28}$ The practical effect of

24. Id. at 614 .

25. Id. at 612 . It has been suggested that treatment of all three newspapers as onc relevant market logically would have required the Court to combine the Publishing Company's morning and afternoon papers in computing the percentage of business controlled by the defendant. Kahn, $A$ Legal and Economic Appraisal of the "New" Sherman and Claytons Acts, 63 Yale L.J. 293, 325 (1954) ; Note, 102 U. of PA. L. Rev. 125, 129 (1953). This would have given a figure of roughly $75 \%$. But the value of such a computation other than for purposes of a rule of reason analysis under $\S 1$ is dubious. Cf. note 16 supra. Once it was established that all three newspapers constituted one market, the unit plan could not be attacked as a tying arrangement. See text at note 26 iifra. Refusals to sell are illegal under the Sherman Act only if they are unreasonable under $\$ 1$. United States v. Colgate \& Co., 250 U.S. 300 (1919). And see Comment, Refusals to Sell and Public Control of Competition, 58 Y ALE L.J. 1121 (1949).

26. "[N]o leverage in one market excludes sellers in the second, because for present purposes the products are identical and the market the same." Times-Picayune Publishing Co. v. United States, 345 U.S. 594, 614 (1953).

27. The Publishing Company's afternoon paper had been purchased from an independent organization in 1933. Id. at 598. The Company's only competitor was the evening Item.

Publication of a morning paper previously owned in conjunction with the Item had been suspended in 1941. Ibid. Prior to its suspension, the Item Company had utilized unit rates, and the fact that the Times-Picayune unit rates for classified advertising were adopted during that period and subsequent to the Item's helped to convince the Court that defendant's plan was adopted for normal business reasons. See $i d$. at 623 . And the fact that the compulsory unit rate for general display advertising had not been adopted until 1950 contributed to the difficulty of showing detriment to the Item. Id. at 618-22. This factor was relevant only when, having decided that the arrangements were not illegal per se, the Court went on to consider whether they nevertheless unreasonably restrained trade. See note 16 and text at note 24 supra. And see Times-Picayune Publishing Co. v. United States, 345 U.S. 594, 627 (1953): "The District Court, and much evidence supports its conclusions, determined that the 1933 purchase ... then seemed a legitimate means of business expansion." Thus, the fact of the purchase did not lend support to the Government's charge of specific intent necessary to a finding of attempt to monopolize.

28. " $[N]$ othing in the record suggests that advertisers viewed the city's nowspaper readers, morning or evening, as other than fungible customer potential. We must assume, therefore, that the readership 'bought' by advertisers in the Times-Picayune, was the selfsame 'product' sold by the States and, for that matter, the Item." Id. at 613. 
finding that morning and afternoon papers sold the same product was to establish a presumption that they were in the same market. And this presumption was decisive, because the Court found "no evidence which could circumscribe a broader or narrower 'market' defined by buy'ers' habits or mobility of demand."29

To justify its refusal to broaden the defendant's market, the Court established a test which would exclude from the relevant market "any other product to which, within reasonable variations in price, only a limited number of buyers will turn."30 However, apparently relying upon its determination that advertising readership constituted a single product, the Court did not apply this test to consider the morning newspaper as a narrower relevant market. ${ }^{31}$ Had the Court made such an analysis, it might have found that the larger circulation of the morning newspaper would preclude advertisers from turning to a competing paper, even though they did not distinguish between morning and afternoon readers.

Times-Picayume's test for defining the market is subject to varying interpretation. One application would require the court to include or exclude a substitute product from the defendant's market on the basis of the number of buyers who would turn to that product should defendant raise his price. But such a determination would depend upon how the product were defined. Evidence that only a limited number of customers would turn to each of a number of other items would require the court to exclude all such items from the defendant's market. However, if the aggregate of buyers who would turn to all these items were a substantial number, the court could reach an opposite result by defining all such items as a single product. Thus, radio, television, and magazines might be excluded from the newspaper market if defined as three products, but included if the customer potential ${ }^{32}$ sold by all three were defined as a single product. ${ }^{33}$

29. Id. at 612 .

30. Id. at $612 \mathrm{n} .31$.

31. The Court explained its exclusion of other advertising medis by reference to the standard set forth, noting that "[t]he advertising industry and its customers . . . marlicdly differentiate between advertising in newspapers and in other mass media." Ibid. However, the only indication that the Court applied the standard to place morning and afternoon papers in the same market appears in its subsequent determination that the three newspapers sold the same product. Id. at 613 . In indicating that proof of "seneric qualities" differentiating their readers might warrant a contrary determination, the Court was following the standard's requirement that the willingness of buyers to substitute one product for another be decisive in defining the market. Ibid. But whether or not readers of two newspagers differed would be only one factor for consideration in determining whether advertisers would substitute one paper for the other.

32. Cf. note 27 supra.

33. Another example of the arbitrary results that might be obtained in applying this market test would be found in defining the market for Coca-Cola. Possible substitute products would be Pepsi-Cola, ginger ale, root beer, orange juice, and beer. Whether the first three would be included in Coca-Cola's market might depend upon whether they were defined as a single product-soft drinks. 
But in Sherman Act tying cases, definition of the market need not be a prerequisite to determining per se illegality. Tying arrangements employ coercive power in one market to eliminate competition in another. Such power might be defined in terms of the amount of business (i.e., number of customers and volume of sales) the defendant would lose if he raised his price. While even a monopolist does not enjoy absolute power over price, ${ }^{34}$ the relationship between a rise in his price and his consequent loss of business would reflect power to coerce..$^{35}$ Under such a test, the nature and number of products to which customers might turn would be irrelevant. Thus in Times-Picayune, evidence that a reasonable rise in the rates of the morning paper would not result in a substantial loss of advertising business would be essential to a fincling of "dominance" in the tying product. This suggestion would be similar to the Court's test in using power over price as the measure of sufficient market power to impose a tying arrangement which would exclude competition. However, under this approach, courts could find such power without defining a relevant market or arbitrarily defining products. And consideration of all defendant's customers-including those who cease using his product without turning to any substitute, and those who turn to substitutes not included in his market-would ensure a more accurate index of market power.

Tying arrangements not illegal per se still may unreasonably restrain trade under Section $1 .{ }^{36}$ Even where a defendant lacks power over price, customers who want the "tied" product may be indifferent to choice of supplier. ${ }^{37}$ Or

34. Monopoly is defined alternatively as power over price, or power to exclude competition. American Tobacco Co. v. United States, 328 U.S. 781, 811 (1946), discussed in Rostow, Monopoly Under the Sherman Act: Power or Purpose?, 43 ItL. L. Rev. 745,762 (1949). And see comparison of monopoly and price-fixing in United States v. Aluminum Co. of America, 148 F.2d 416, 428 (2d Cir. 1945).

35. As a firm approaches monopoly power, it will be able to raise prices without unduly decreasing sales. See Samuelson, Economics-An Introductory Anslysis 493 (1948). If the firm's price is at its optimum point, a rise in prices will to some extent decrease revenue but sales will not fall a substantial amount. The monopolist who is charging less than his optimum price will be more successful in increasing price without losing revenue or business.

36. See note 16 supra. The district court, which held the Publishing Company's unit plan illegal under $\S 1$, did not label it illegal per se. United States v. Times-Picayune Publishing Co., 105 F. Supp. 670 (E.D. La. 1952). A motion for partial summary judgment, which would have "labeled forced combination selling ... a Sherman Act violation without evidence of intent or actual effect on competitors" was denied. Comment, Local Monopoly in the Daily Newspaper Indistry, 61. YALE L.J. 948, 1004 n.295 (1952).

37. See United States v. Investors Diversified Services, Inc., 102 F. Supp. 645 (D. Minn. 1951), discussed in Kahn, A Legal and Economic Appraisal of the "New" Sherman and Clayton Acts, 63 Y ALE L.J. 293, 330 n.192 (1954). A fact situation like that in Intcrnational Salt, where lessees were required to purchase salt that they needed for use in the lessor's machines exclusively from the lessor, might also be an example. International Salt Co.v. United States, 332 U.S. 392 (1947). 
the disadvantage involved in the purchase of a "tied" product may be insubstantial where the "tying" product represents a large, permanent investment. ${ }^{38}$ But whether the effect of the arrangement would be unreasonably to restrain trade would depend in part upon defendant's market position. ${ }^{33}$ In the GMAC case, ${ }^{40}$ where General Motors tied financing to automobile sales, the court considered what it called GMrs "dominant" position in the automobile industry and GM's sole command over the supply of its cars." Similarly, in Times-Picayune, the district court looked at both the morning newspaper's relative superiority among New Orleans newspapers and its monopoly in the morning field to evaluate its market position. ${ }^{42}$ Thus both courts took a dual approach to market definition, looking not only at the position of the tying product in the entire relevant market, but also at that product as a separate market. This treatment of defendant's market position was neither rejected nor approved by the Supreme Court; the Court's determination that the Publishing Company sold a single product in a single market precluded consideration of its unit plan as a tying arrangement. ${ }^{3}$ However, such an approach seems sound where distinctive characteristics of a tying product permit a defendant whose relative position among competitors falls short of monopoly unreasonably to restrain trade by tying arrangements.

Times-Picayune could lead to a new standard of legality for those tying

38. See United States v. General Miotors Corp., 121 F.2d 376 (7th Cir. 1941). And see text at note 6 supra. Although there was some evidence that "many purchasers could only buy a car on a small down payment and long terms, neither of which was available under the GMAC plan," the fact that GMI found it profitable to continue with the arrangements would seem to indicate that the natural desire of customers to satisfy their first choice in so substantial an investment as a new car outweighed the disadvantages of the finaneing plan. United States v. General Motors Corp., supra at 396.

39. One factor to be considered in evaluating the reasonableness of a restraint of trade is the "strength of the remaining competition." Supra note 16. Since tying arrangements are prohibited primarily because of their effect upon competition in the "ticd" marliet, position in that market may also be relevant for a "rule of reason" analysis. Thus, in the GIIAC case, the Court noted that GMAC was the largest automobile financing company in the world. United States v. General Motors Corp., 121 F.2d 376, 398 (7th Cir. 1941).

40. Id. at 376 .

41. Id. at 403. After noting that General Motors "had achieved a dominant position in the automobile industry as manufacturer of cars desired by dealer-purchasers and many* members of the retail public," the Court added: "[O]f course, the utilization of the manufacturer's dominant position and the tremendous popularity of General Mlotors automobiles, among other things heretofore explained, made it possible for the appellants to force the sale of the related finance service" Id. at 400 . The only evidence of GAP's "dominant position" in the industry considered by the Court was the fact that GM was the largest producer. Id. at 398 .

42. United States v. Times-Picayune Publishing Co., 105 F. Supp. 670,674 (E.D. La. 1952). In discussing the Times-Picayune's market position, the court pointed to its "monopoly position in the morning field, and an enormous advantage in circulation, advertising linage and number of printed pages...." Ihid.

43. See text at notes 22,26 supra. 
arrangements-including buyers' practices ${ }^{44}$-not encompassed by the Clayton Act. Where a substantial volume of commerce in a "tied" market is affected, per se illegality should result from a finding that defendant has power over price in the "tying" market. But where conditions for per se illegality are not met, the distinctiveness of the tying product should be considered, in addition to defendant's degree of power in the entire relevant market for it, as a factor which may result in an unreasonable restraint of trade.

44. See note 12 supra.

Power over price measures the extent to which a seller's command over supply of goods enables him to exclude competition. The buyer's counterpart, command over market outlets, is also measurable in terms of power over price. See stipra note 34. Thus, monopoly buying power (or monopsony) could be analyzed in terms of the volume of supplies a buyer would lose if he lowered the price he was willing to offer. 